\title{
Still Policing the Crisis: A Seminar and Panel Discussion on Stuart Hall's Relevance in the Current Conjuncture
}

\author{
Sponsored by \\ Simon Fraser Institute for the Humanities, School of Communication, \\ and the Faculty of Communication, Art and Technology \\ SFU Harbour Centre, Room 2270, October 9, 4-6 pm \\ Session Chair: Scott Timcke, School of Communication, Simon Fraser University \\ Scott Timcke completed his PhD in Communication at Simon Fraser University and works in the areas \\ of social theory and political philosophy, media and technology studies, global inequality studies, and \\ African studies. His most recent publication is "The Imperial Republic and Pax Americana: State For- \\ mation, Inequality and the New American Way of War," in the online journal TripleC.
}

\section{Grant Farred, Chair of Africana Studies, Cornell University}

Foucault's Secret Admirer: The Biopolitics at the Core of Stuart Hall's 'Policing the Crisis'

Grant Farred has published in the areas of postcolonial theory, race, formation of intellectuals, sport's theory, and cultural studies and literary studies. He is author or editor of 5 books, the most recent of which is Bodies in Motion, Bodies at Rest (University of Minnesota Press, 20150. He was the editor of the South Atlantic Quarterly for more than a decade, including editing a special issue of SAQ (2004) entitled After the Thrill Is Gone: A Decade of Post-Apartheid South Africa, an appraisal of South African democracy, its failure and its successes, in the post-apartheid era.

\section{Ben Carrington, Department of Sociology, University of Texas (Austin)}

Living the Crisis Through 10 Moments

Ben Carrington has written widely on a range of topics including the sociology of race, gender and culture, post/colonial theory, Marxism and culture, sports studies, media studies, youth culture and music. He is especially interested in how ideologies of race shape - and are themselves shaped by - cultural forms, practices and identities and how popular culture is often a key site of both cultural resistance and domination. He has published 4 books and is currently working on a new ethnographic project examining the contemporary state of black cultural politics within the Caribbean diaspora.

\section{Sut Jhally, Department of Communication, University of Massachusetts}

Policing the Crisis - Race, Class \& State Violence in Neoliberalism

Professor Sut Jhally is the founder and executive director of the Media Education Foundation, an internationally renowned producer of innovative educational video materials. He has also written widely in the areas of media studies, cultural studies and the political economy of communication. He is the author of 6 books, the most recent of which is The Spectacle of Accumulation: Essays in Media, Culture and Politics. Professor Jhally is also the recipient of an honorary doctorate in 2015 from Simon Fraser University. 